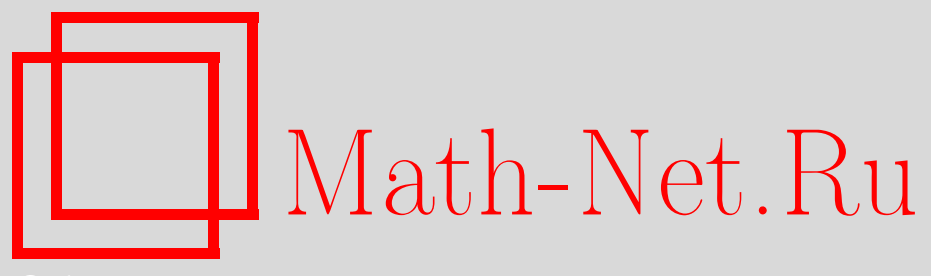

Д. Ю. Бураго, Ю. Д. Бураго, А. Л. Вернер, А. М. Вершик, М. Л. Громов, И. А. Ибрагимов, С. В. Иванов, С. В. Кисляков, С. С. Кутателадзе, А. А. Лодкин, Ю. В. Матиясевич, Н. Е. Мнёв, А. И. Назаров, Г. Ю. Панина, Ю. Г. Решетняк, В. А. Рыжик, Н. Н. Уральцева, Я. М. Элиашберг, Виктор Абрамович Залгаллер (некролог), УМН, 2021, том 76, выпуск 5, 195-198

DOI: https://doi.org/10.4213/rm10022

Использование Общероссийского математического портала Math-Net.Ru подразумевает, что вы прочитали и согласны с пользовательским соглашением http://www . mathnet.ru/rus/agreement

Параметры загрузки:

IP : 35.174 .16 .151

26 апреля 2023 г., 14:09:54

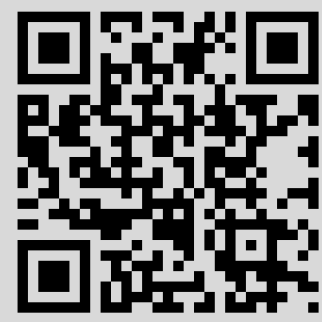




\section{Виктор Абрамович Залгаллер}

2 октября 2020 г., не дожив двух с небольшим месяцев до своего столетнего юбилея, скончался выдающийся представитель СанктПетербургской геометрической школы, почётный член Санкт-Петербургского математического общества профессор Виктор Абрамович Залгаллер.

Виктор Абрамович родился 25 декабря 1920 г. в деревне Парфино Новгородской губернии в семье инженера Абрама Леонтьевича Залгаллера и адвоката Татьяны Марковны Шабад-Залгаллер. В 1922 г. семья переехала в Петроград. В 1931 г. отец был репрессирован по 58-й статье и провёл в Ухтпечлаге 16 лет сначала в заключении, потом в ссылке.

Окончив в 1937 г. школу № 103 Смольнинского района Ленинграда, Виктор поступил на математико-механический факультет Ленинградского университета. Его способности были замечены лектором по математическому анализу Л.В. Канторовичем, который по-

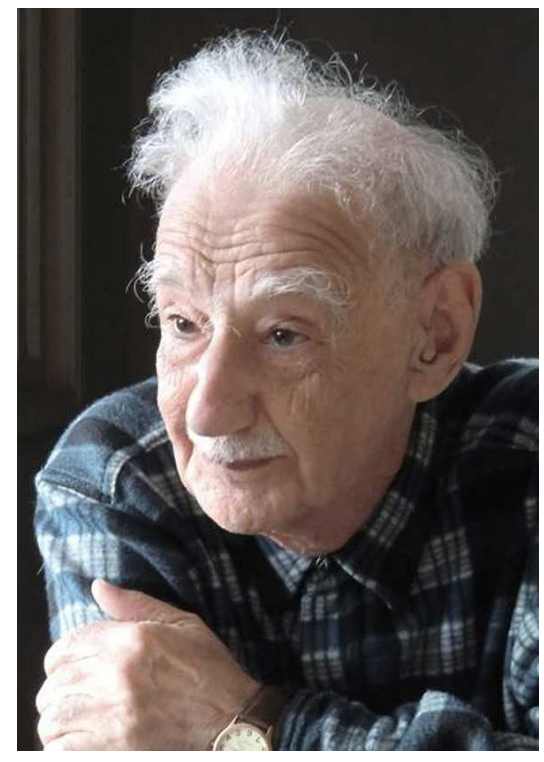
ручил третьекурснику подготовить учебное пособие на основе своего конспекта.

В 1940 г. Виктор Абрамович перешёл по комсомольской мобилизации в авиационный институт, где получил инженерное образование, сыгравшее значительную роль в его дальнейшей научной судьбе.

С первых дней войны он добровольцем вступил в ряды Народного ополчения (Вторая дивизия) и почти сразу был отправлен на фронт. Почти всю войну он был связистом. Нелёгким был боевой путь Виктора Залгаллера: оборона Ленинграда, Ораниенбаумский плацдарм, ранение при снятии блокады, штурм Выборга, бои в Прибалтике, штурм Данцига, выход на Эльбу. . . Виктор Абрамович был награждён орденом Красной Звезды, медалью “За отвагу", тремя медалями "За боевые заслуги", медалью "За оборону Ленинграда" и другими. Закончил войну в звании старшего сержанта. Его младший брат, лейтенант Леонид Залгаллер, погиб в 1942 г., попав в окружение под Мясным Бором.

После демобилизации Виктор Абрамович вернулся на 3-й курс матмеха. В 1948 г. он с отличием окончил математико-механический факультет по кафедре геометрии и в том же году поступил на работу в ЛОМИ (Ленинградское отделение Математического института АН СССР, ныне - ПОМИ РАН), где проработал более 50 лет. Начиная с 1950 г. он много лет по совместительству читал лекции на матмехе ЛГУ (СПбГУ). В 1999 г. по семейным обстоятельствам переехал в Израиль, был консультантом в Институте им. Х. Вейцмана в Реховоте, где в честь его 80- и 90-летия были организованы конференции.

DOI: https://doi.org/10.4213/rm10022 
Виктор Абрамович хорошо понимал инженерные задачи и умел находить общий язык с инженерами. В первые годы после окончания университета он активно сотрудничал с Л.В. Канторовичем, который привлёк его к работам по оптимальному раскрою материалов и направил на Ленинградский вагоностроительный завод им. И.Е. Егорова для практической проверки своих идей. Их совместная деятельность увенчалась публикацией книги "Расчёт рационального раскроя промышленных материалов" (Лениздат, Л., 1951, 206 с.; 3-е изд.: Невский диалект, СПб., 2012). Книга оказалась одновременно интересна математически и чрезвычайно полезна в конкретных задачах раскроя металла, лесоматериалов, кожи и т.п. Многие вопросы линейного программирования и его применения в книге освещались впервые в мире. В частности, рекомендации, предложенные В. А. Залгаллером, предвосхитили некоторые идеи динамического программирования, развитого Р. Беллманом.

В дальнейшем инженеры часто обращались к Виктору Абрамовичу за консультациями. В конце 1950-х годов он читал инженерам математический анализ на курсах повышения квалификации, причём аудитория выросла за время чтения курса почти вдвое. Виктор Абрамович подчёркивал, что ему важна заинтересованность человека, он не боялся, что собеседник может быть слаб в математике.

Остановимся теперь на работах В.А. Залгаллера по геометрии. В 1950-1952 гг. под влиянием своего учителя А. Д. Александрова он опубликовал серию статей по теории кривых с ограниченной вариацией поворота и по внутренней геометрии выпуклых поверхностей. Очень быстро Виктор Абрамович стал ключевым участником знаменитого Александровского семинара.

Развивая пионерские идеи Александрова, Залгаллер построил теорию двумерных многообразий ограниченной кривизны. В 1963 г. он защитил докторскую диссертацию по совокупности работ.

Важный результат В.А. Залгаллера родственен теореме Нэша-Кейпера и утверждает, что всякий $d$-мерный полиэдр допускает кусочно линейную внутреннюю изометрию в $d$-мерное евклидово пространство. Виктор Абрамович доказал этот факт для $d=2,3,4$, но его методы позволили позже обобщить теорему на произвольную размерность. В 1990-е годы Виктор Абрамович вернулся к этой тематике и доказал (совместно с Ю.Д. Бураго) существование кусочно линейных изометрических вложений и погружений двумерных полиэдральных поверхностей в трёхмерное пространство.

Неоднократно обращался Виктор Абрамович к теории выпуклых множеств. Его интересовала связь между свойствами внутренних метрик выпуклых поверхностей и их внешней геометрией. Сюда же относятся исследования поведения кратчайших на выпуклой поверхности, в частности построение первого примера кратчайшей, не проходящей через ребристые точки и имеющей неспрямляемый сферический образ. Кроме того, Виктор Абрамович занимался приложением теории выпуклых множеств к вероятностным задачам, в частности к вопросу о вероятности попадания в выпуклую область при нормальном распределении. Инструментом здесь послужила теория смешанных объёмов. Сюда же примыкает совместное исследование В. А. Залгаллера с В.Н. Судаковым одной экстремальной задачи, связанной с нормальным распределением, в случае центрально симметричного выпуклого тела.

Любому математику, разобравшемуся в классификации платоновых тел, приходит в голову вопрос: а какие бывают (выпуклые) многогранники, у которых все грани правильные многоугольники, но не обязательно одинаковые между собой? Этот вопрос гораздо сложнее, чем может показаться на первый взгляд, и В. А. Залгаллеру принадлежит его решение: существует ровно 28 простых (не составленных из других) правильногранных многогранников, не считая призм и антипризм.

Много работ В.А. Залгаллера посвящено экстремальным задачам для выпуклых множеств, этой необъятной темой он занимался всю жизнь. Отметим замечательное 
достижение, полученное в период жизни Виктора Абрамовича в Израиле: совместно с А. Ю. Солыниным он доказал старую гипотезу Полиа и Сеге о том, что логарифмическая ёмкость плоского $n$-угольника заданной площади достигает минимума на правильном $n$-угольнике. Их доказательство красиво и не просто. Оно состоит из двух частей, геометрической и аналитической, и как раз первая принадлежит В. А. Залгаллеру. Здесь потребовалась очень специальная триангуляция $n$-угольника. Как Виктор Абрамович рассказывал коллегам, он непрерывно размышлял об этой задаче больше года, и в конце концов её решение открылось ему во сне. Доказательство этой гипотезы стало одним из лучших подарков на его 80-летие. В 2004 г. этот результат был опубликован в престижнейшем журнале "Annals of Mathematics".

Последняя математическая публикация Виктора Абрамовича датируется 2012 годом.

В.А. Залгаллер - автор нескольких математических книг, вошедших в золотой фонд математической литературы. Наиболее известны и любимы геометрами (кроме уже упомянутой монографии о раскрое материала) следующие.

- А.Д. Александров, В.А. Залгаллер, Двумерные многообразия ограниченной кривизны: Основы внутренней геометрии поверхностей (Труды МИАН СССР, 63 (1962), 3-262) - основополагающее исследование внутренних метрик и их кривизны на двумерных многообразиях. В этой книге введено одно из важнейших понятий современного геометрического анализа - метрика с ограниченной в интегральном смысле кривизной.

- Ю. Д. Бураго, В. А. Залгаллер, Геометрические неравенства (Наука, Л., 1980, 288 с.; существенно переработанное издание вышло в 1988 г. в издательстве Шпрингер) - настоящая энциклопедия, посвящённая разнообразным неравенствам для подмножеств евклидовых и римановых пространств, настольная книга лекторов по геометрии на математических факультетах, ставшая преемником классической монографии Т. Боннезена и В. Фенхеля.

- Ю. Д. Бураго, В. А. Залгаллер, Введение в риманову геометрию (Наука, СПб., 1994, 318 с.; в 2018 г. вышло второе издание) - единственный учебник римановой геометрии на русском языке, где изложение ведётся с точки зрения "римановой геометрии в целом" и при этом подходит для начального знакомства с предметом.

Среди разнообразных задач, привлекавших внимание Виктора Абрамовича, находилось место и "занимательной математике". Например, в статье, написанной им совместно с женой, С. И. Залгаллер, для журнала "Квант" в 1980 г., дано описание группы преобразований кубика Рубика и предложен алгоритм его сборки.

Виктор Абрамович был выдающимся преподавателем с необычайной способностью наглядно демонстрировать самые сложные идеи. Его отличало особенное дружелюбие по отношению к студентам и вообще молодёжи. Несколько поколений студентов вспоминают его как лучшего лектора их курсов. Среди его непосредственных учеников наиболее известным является Г. Я. Перельман.

Невозможно не упомянуть об общественной деятельности В. А. Залгаллера на благо математики и математического образования - деятельности, органично вытекавшей из его характера. В начале 1950-х годов он был активным участником борьбы против попыток марксистских философов объявить целые разделы математики лженаукой, одним из авторов и редакторов выдающегося труда "Математика, её содержание, методы и значение" (1953). А почти сорок лет спустя сыграл важную роль в защите здания ЛОМИ от попыток захвата.

Виктор Абрамович всегда любил работать со школьниками и студентами. Ещё в 1946 г. он пришёл во Дворец пионеров руководителем математического кружка. "У меня были неплохие мальчики, - вспоминал Виктор Абрамович, - Юра Решетняк, Гаральд Натансон, Миша Соломяк - всё это мальчики из моего кружка". (Все трое впоследствии стали крупными математиками.) Он был в числе организаторов 
специализированной математической школы № 239, одной из первых в Советском Союзе, для которой разработал первую учебную программу и в которой сам преподавал в 1961-1962 гг. В дальнейшем он поддерживал тесную связь со школой. В своей монографии "Выпуклые многогранники с правильными гранями" (Зап. науч. сем. ЛОМИ, 2 (1967), 5-221), которую Виктор Абрамович посвятил своему учителю А. Д. Александрову, автор благодарит 12 учеников 239-й школы, помогавших ему в вычислениях. Это редкий случай благодарности школьникам в серьёзном научном труде.

Отдельно следует сказать о литературной одарённости Виктора Абрамовича. Широкую известность получили его военные мемуары "Быт войны", написанные замечательным безыскусным языком. Им написаны прекрасные эссе о старших коллегах и учителях - И. П. Натансоне, Л. В. Канторовиче, А. Д. Александрове. В 1970-х годах Виктор Абрамович провёл обширные архивные и литературные изыскания, результатом которых стал уникальный труд, посвящённый истории здания ЛОМИ, знавшего Пушкина, Жуковского, Карамзина, декабристов. ${ }^{1}$

Коллеги, многочисленные ученики, друзья и близкие сохранят память о Викторе Абрамовиче Залгаллере как о ярком учёном драматической судьбы, выдающемся педагоге, личности исключительной нравственности и принципиальности, - и в то же время просто как о добром и обаятельном человеке.

Д. Ю. Бураго, Ю.Д. Бураго, А. Л. Вернер, А.М. Вериик, М. Л. Громов, И. А. Ибрагимов, С. В. Иванов, С. В. Кисляков, С. С. Кутателадзе, А.А. Лодкин, Ю.В. Матиясевич, Н. Е. Мнёв, А.И. Назаров, Г. Ю. Панина, Ю.Г. Решетняк, В.А. Ръжик, Н. Н. Уральщева, Я. М. Элиашберг

\footnotetext{
1Эти произведения, а также материалы о жизни и творчестве В. А. Залгаллера можно найти в книге "Война и мир ленинградского математика. К 100-летию со дня рождения Виктора Залгаллера" (Аврора, СПб., 2021).
} 